\title{
Hyperosmotic Environment Blunts Effectivity of Ischemic Preconditioning Against Ischemia-Reperfusion Injury and Improves Ischemic Tolerance in Non-Preconditioned Isolated Rat Hearts
}

\author{
M. ZÁLEŠÁK ${ }^{1}$, P. BLAŽÍČEK ${ }^{2}$, D. PANCZA ${ }^{1}$, I. GABLOVSKÝ ${ }^{1}$, V. ŠTRBÁK ${ }^{3}$, \\ T. RAVINGEROVÁ ${ }^{1}$ \\ ${ }^{1}$ Institute for Heart Research, Slovak Academy of Sciences, Bratislava, Slovak Republic, \\ ${ }^{2}$ Laboratory of Clinical Biochemistry and Hematology Alpha Medical, Bratislava, Slovak Republic, \\ ${ }^{3}$ Institute of Experimental Endocrinology, Slovak Academy of Science, Bratislava, Slovak Republic
}

Received April 11, 2016

Accepted October 14, 2016

\section{Summary}

Several studies have shown that diabetes mellitus modulates heart resistance to ischemia and abrogates effectivity of cardioprotective interventions, such as ischemic preconditioning (IP). The aim of this study was to evaluate whether the effect of hyperglycemic conditions on the severity of ischemia-reperfusion (I/R) injury in preconditioned and non-preconditioned hearts (controls, C) is related to changes in osmotic activity of glucose. Experiments were performed in isolated rat hearts perfused according to Langendorff exposed to 30-min coronary occlusion/ 120-min reperfusion. IP was induced by two cycles of 5-min coronary occlusion/5-min reperfusion, prior to the long-term I/R. Hyperosmotic ( $\mathrm{HO})$ state induced by an addition of mannitol $(11 \mathrm{mmol} / \mathrm{l})$ to a standard Krebs-Henseleit perfusion medium significantly decreased the size of infarction and also suppressed a release of heart fatty acid binding protein (h-FABP - biomarker of cell injury) from the non-IP hearts nearly to $50 \%$, in comparison with normoosmotic (NO) mannitol-free perfusion. However, IP in $\mathrm{HO}$ conditions significantly increased the size of infarction and tended to elevate the release of h-FABP to the effluent from the heart. The results indicate that $\mathrm{HO}$ environment plays a cardioprotective role in the ischemic myocardium. On the other hand, increased osmolarity, similar to that in the hyperglycemic conditions, may play a pivotal role in a failure of IP to induce cardioprotection in the diabetic myocardium.

\section{Key words}

Ischemia-reperfusion injury - Ischemic preconditioning • Hyperglycemia • Hyperosmosis • Diabetes mellitus

\section{Corresponding author}

M. Zálešák, Institute for Heart Research, Slovak Academy of Science, P.O. BOX 104, Dúbravská cesta 9, 840 05, Bratislava, Slovak Republic. E-mail: mzmzalesak@gmail.com

Several experimental and clinical studies have shown that some pathological conditions, such as acute diabetes mellitus (DM), hyperglycemia, and/or angina pectoris (AP, considered as a clinical analogue of ischemic preconditioning, IP) modulate heart resistance against ischemia-reperfusion ( $\mathrm{I} / \mathrm{R})$ injury. The resulting effect depends on the duration of pathological conditions and their combination (Ferdinandy et al. 2007, Ravingerová et al. 2012). Diabetes mellitus induced by streptozotocin (STZ-DM) in its early phase activates cytoplasmatic protein kinases also involved in physiological processes likewise cell growth or IP (PI3 kinase, protein kinase B, C, MAP kinases, such as extracelular signal-regulated kinases $1 / 2$, endothelial NO-syntase). Duration of diabetic state markedly determines myocardial response to $I / R$. It has been proposed that acute phase of STZ-DM improves heart resistance against I/R injury (Ravingerová et al. 2003a, Ravingerová et al. 2000). However, longer period of DM alters cardiac tolerance to ischemia (Ravingerová et al. 2003b, Tosaki et al. 1996). Chronic phase of the disease leads to alterations of DM-induced intracellular signaling which results in impaired maintenance of physiological regulations and subsequent development of pathological 
processes (Ravingerová et al. 2010, Balakumar 2014). Moreover, hyperglycemia may completely blunt cardioprotection induced by IP applied in the in vivo conditions (Kernsten et al. 1998, Vladic et al. 2011). It was also observed that prognosis of infarction in patients with short-term episodes of pre-infarction AP is worse in those with DM (Behar et al. 1992, Ishihara et al. 2001). Similarly, hyperglycemia in the in vitro conditions simulated by an enhanced concentration of glucose in the perfusion medium reversed beneficial effect of IP and increased susceptibility of preconditioned isolated hearts to I/R injury (Zálešák et al. 2014). The mechanism of IP implies releasing of mediators from stressed myocytes and paracrine stimulation of appropriate receptors coupled with G-proteins. Releasing of specific mediators is facilitated by cell swelling during brief $I / R$ stress related to impaired sodium homeostasis, decreased ATP content ( $\mathrm{Li}$ and He 1995) and accumulation of products of anaerobic glycolysis (Štrbák 2011). It was observed that hypotonic environment also facilitates releasing of these mediators from the cells (Phillips and O'Regan 2002). It suggests that the hypertonic environment due to hyperglycemia may cause the failure of IP-induced cardioprotection.

On the other hand, hypertonicity may induce an adaptive response to hyperosmotic stress. The hyperosmotic response stress pathway has been well characterized by activation of osmotic sensor proteins S11 and Sho2 which upregulates multiple protein kinases involved in IP-mechanisms (Alfieri and Petronini 2007). In addition, hyperosmotic conditions induced by abundant glucose or presence of metabolically inactive mannitol in perfusion medium increased expression of heat shock protein 90 (Chen et al. 2006). This study also showed that acute STZ-induced DM reduced releasing of creatinkinase from hearts during reperfusion in Langendorff mode. However, it was not elucidated if and how the hypertonicity itself regardless elevated glucose, influences myocardial resistance against ischemia.

This study aimed to elucidate the efficacy of hypertonicity induced in vitro on resistance of preconditioned and non-preconditioned hearts to $\mathrm{I} / \mathrm{R}$ injury without elevated energy availability. Adult male Wistar rats (250-300 g) handled in accordance with the Guide for the care and Use of laboratory Animals published by US National Institutes of Health (NIH publication No 85-23 revised 1996) and approved by the Animal Health and Food Administration of the Slovak Republic were used in the study. Rats were randomly divided into four groups, and further experiments were performed in Langendorff-perfused hearts.

After rapid excision, the hearts were placed into ice-cold physiologic buffer, cannulated via aorta and perfused in the Langendorff mode with Krebs-Henseleit buffer (KHB) gassed with $95 \% \mathrm{O}_{2}$ and $5 \% \mathrm{CO}_{2}$ $(\mathrm{pH}=7.4)$ at a constant perfusion pressure of $73 \mathrm{~mm} \mathrm{Hg}$ and $37^{\circ} \mathrm{C}$. Standard (normoosmotic, NO) KHB contained (in mmol/l): $\mathrm{NaCl} 118.0, \mathrm{KCl} 3.2, \mathrm{MgSO}_{4} 1.2, \mathrm{NaHCO}_{3}$ 25.0, $\mathrm{KH}_{2} \mathrm{PO}_{4}$ 1.18, $\mathrm{CaCl}_{2}$ 2.5, glucose 11.1 and hyperosmotic (HO) KHB buffer was enriched with mannitol 11.1. Osmolarity of both buffers was 290 and $325 \mathrm{mOsm} / \mathrm{l}$, respectively, evaluated by the cryoscopic osmometer (OSMOMAT 030, Gonotec, Germany). Left ventricular (LV) pressure was measured by a water-filled balloon (inflated to obtain end-diastolic pressure of 5-7 mm Hg inserted into LV) and connected to a pressure transducer (MLP physiological pressure transducer, ADinstruments, Germany). LV systolic and diastolic pressure, LV developed pressure (LVDP, systolic minus diastolic pressure), maximal rates of pressure development and fall, $+\mathrm{dP} / \mathrm{dt}_{\max },-\mathrm{dP} / \mathrm{dt}_{\min }$, as indexes of contractions and relaxation, heart rate (HR, derived from electrogram) and coronary flow were used to assess heart function using Power-Lab/8S5P Chart 7 software (ADinstruments Germany). The hearts were allowed to stabilise (normal perfusion) $20 \mathrm{~min}$ before further interventions. No significant differences in the values of heart rate, $\mathrm{LVDP},+\mathrm{dP} / \mathrm{dt}_{\max },-\mathrm{dP} / \mathrm{dt}_{\max }$ and coronary flow between all groups were observed (Table 1). After stabilization period, hearts were exposed to 30-min occlusion of left anterior descending (LAD) coronary artery followed by a release of clamping and 120-min reperfusion for to provide $\mathrm{I} / \mathrm{R}$ injury. Groups of hearts perfused during whole $\mathrm{I} / \mathrm{R}$ protocol with mannitol-free KHB served as a normoosmosis (NO) and with mannitol rich-KHB as a hyperosmosis (HO). IP was induced in both conditions (NO, HO) by two cycles of 5-min coronary artery occlusion and 5-min reperfusion prior to sustained I/R performed like in both NO and HO nonpreconditioned groups served as a controls.

The severity of $I / R$ injury or heart resistance were determined based on the evaluation of infarct size at the end of $I / R$ protocol and release of heart type fatty acid binding protein (h-FABP), considered as a rapid biomarker of cell injury (Alhadi and Fox 2004), from the hearts to perfusion medium during the whole experiment. Infarct size (IS) and area at risk (AR) were delineated by double-staining with $\mathrm{KMnO}_{4}$ and triphenyltetrasolium 
Table 1. Preischemic values of parameters of myocardial function.

\begin{tabular}{lcccc}
\hline Group & I/R/NO & IP/NO & I/R/HO & IP/HO \\
\hline$H R$ (beats/min) & $254 \pm 16$ & $238 \pm 16$ & $228 \pm 16$ & $202 \pm 18$ \\
$C F(\mathrm{ml} / \mathrm{min})$ & $8.7 \pm 1.0$ & $10 \pm 1.0$ & $8.3 \pm 0.8$ & $6.7 \pm 0.5$ \\
$L V D P(\mathrm{~mm} \mathrm{Hg})$ & $74.7 \pm 9.9$ & $76.8 \pm 9.6$ & $75.2 \pm 6.5$ & $64.4 \pm 5.6$ \\
$+d P / d t_{\max }(\mathrm{mm} \mathrm{Hg})$ & $1959 \pm 290$ & $1995 \pm 349$ & $2334 \pm 204$ & $1326 \pm 110$ \\
$-d P / d t_{\max }(\mathrm{mm} \mathrm{Hg})$ & $1138 \pm 206$ & $1164 \pm 213$ & $1819 \pm 738$ & $1027 \pm 93$ \\
\hline
\end{tabular}

I/R - non-preconditioned controls, IP - ischemic preconditioning, HO - hyperosmosis, NO - normoosmotic conditions, HR - heart rate, CF - coronary flow, LVDP - left ventricular developed pressure, $+(\mathrm{dp} / \mathrm{dt})_{\max }-$ maximal rate of pressure development, $-(\mathrm{dP} / \mathrm{dt})_{\max }-$ maximal rate of pressure fall. Data are expressed as a means \pm SEM, $n=6-8$ hearts per group.
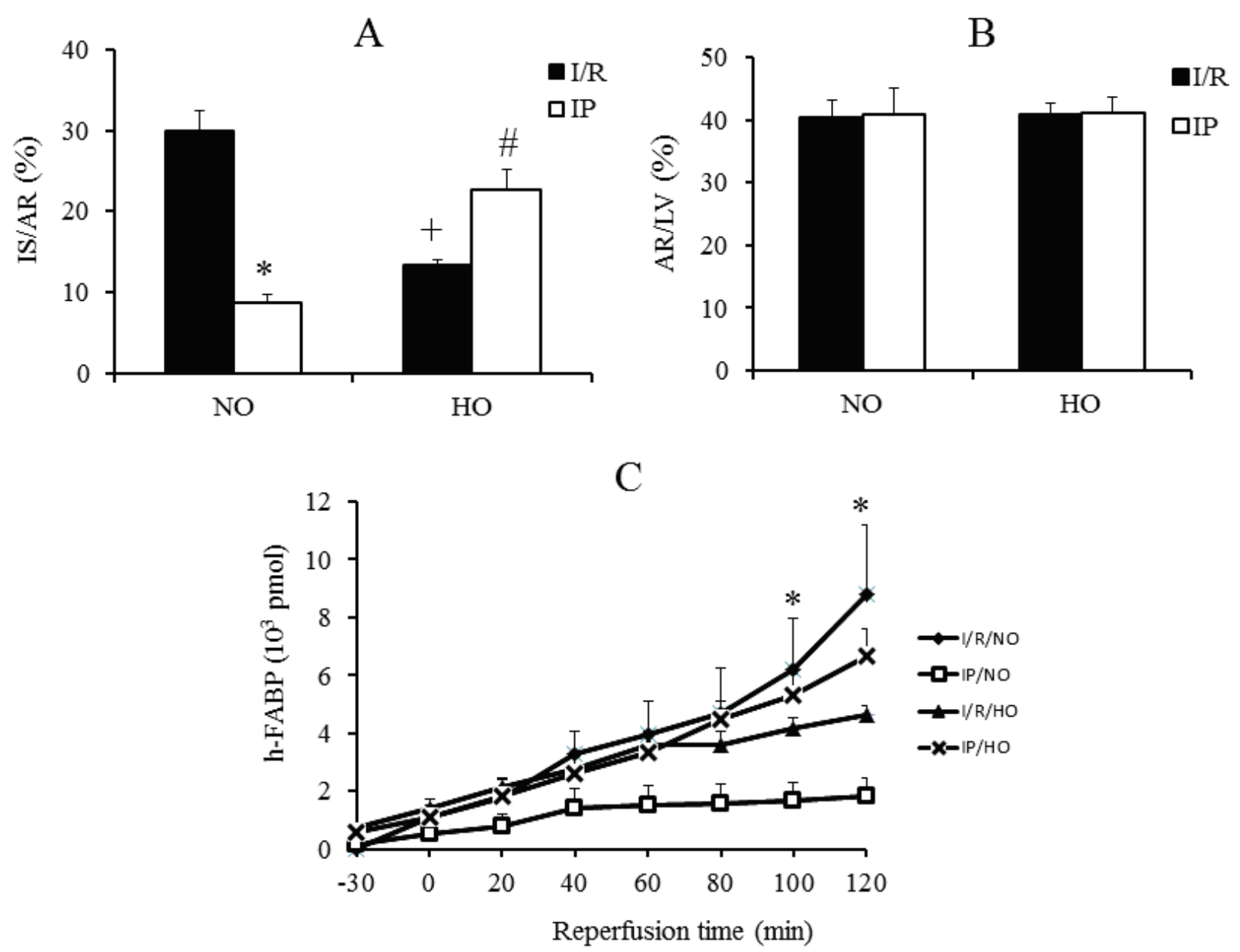

Fig. 1. Effect of hyperosmotic conditions (HO) and ischemic preconditioning (IP) to heart sensitivity to $I / R$ injury in comparision with normoosmotic (NO) conditions. A. Infarct size (IS) of area at risk (AR) in \%. B. AR of left ventricle (LV) in \%. C. Cummolative curves of total amount of $\mathrm{h}$-FABP substance released from hearts to perfusing medium in respective stages of experiments in normoosmotic (NO) and hyperosmotic $(\mathrm{HO})$ conditions. I/R - non-preconditioned controls, IP - ischemic preconditioning. Results are expressed as a means $\pm \mathrm{SEM}, \mathrm{n}=6-8$ hearts per group, $* \mathrm{p}<0.05, \mathrm{IP} / \mathrm{NO}$ vs. I/R/NO, $\mathrm{p}<0.05, \mathrm{I} / \mathrm{R} / \mathrm{NO}$ vs. I/R/HO, \# $\mathrm{p}<0.05, \mathrm{IP} / \mathrm{HO}$ vs. I/R/HO.

chloride (TTC), as described elsewhere (Neckár et al. 2007). IS and AR were measured in 4-5 left ventricle slices per heart (1 mm thick) and determined by noncommercial planimetric software. IS was expressed in $\%$ of AR. No significant differences in AR in LV slices
$(\mathrm{AR} / \mathrm{LV})$ were observed between the groups (Fig. 1B). H-FABP was analyzed in the effluent from the hearts using sandwich ELISA test kit according to a datasheet of manufacturer to determine h-FABP concentrations. Effluent from the hearts was collected during 
stabilization, long-term occlusion and reperfusion period. Collecting during reperfusion was divided into series of six $20 \mathrm{~min}$ separated collectings. Samples $(2 \mathrm{ml})$ of collected effluent in each experimental stage were dialyzed overnight against redistilled water at $4{ }^{\circ} \mathrm{C}$ using dialysis tubing cellulose membrane, 1-ml samples obtained from dialyzed samples were frozen at $-20^{\circ} \mathrm{C}$, completely lyophilized and subsequently diluted with $110 \mu \mathrm{l}$ sample diluent. In diluted samples $(100 \mu \mathrm{l})$ h-FABP concentrations were determined using ELISA. Concentrations values were multiplied by appropriate volumes of collected effluents to determine the amount of h-FABP substance (in pmol) released in every experimental stage. With respect to the sample processing, amounts of substances were multiplied by 0.09 . This constant represents a simplified numeric expression of $100 / 1000 \times 100 / 110$. Gradual summations of h-FABP amount are expressed in cumulative curves (Fig. 1C) and show the total amount of h-FABP released in each phase of experiment. The h-FABP release was observed also during coronary occlusion in all groups. Its potential cause is a basal h-FABP release from normal non-risk myocardium or coronary collateral development in AR, which become functional between 15 to $30 \mathrm{~min}$ of coronary occlusion according to morphological study in rats (Jia and Sato 1997).

In our experiments, $\mathrm{HO}$ in non-preconditioned controls significantly reduced IS/AR (Fig. 1A) and total amount of h-FABP substance released at the end of reperfusion was suppressed nearly to $50 \%$ as compared to the standard NO conditions (Fig. 1C). It confirms that HO conditions exert cardioprotective effects. Beneficial effect of hypertonicity and related prevention of release of molecular substances (creatine phosphokinase) from the myocytes is also supported by experimental study of Cao et al. (2013). Similarly, in vivo experiments in pigs confirmed the favorable effects of hyperosmotic environment induced by intracoronary application of mannitol. In that study, hyperosmosis mitigated irreversible reperfusion injury, infarct size and cell swelling in the risk myocardium (Garcia-Dorado et al. 1992). However, cardioprotection induced by hyperosmotic environment is not obvious. Thus, other studies in porcine (Klein et al. 1985) or dog myocardium (Carlson et al. 1992) did not show an improved heart resistance by intracoronary administration of mannitol in the in vivo models. The probable cause of this ambivalent effect of hyperosmotic treatment may be related to parallel activation of both $\mathrm{Ca}^{2+}$-induced cell death and survival, supported by activation of the transcriptional factor cAMP responsive element binding protein (CREB) (Chiong et al. 2010). It was determined that CREB is a downstream target of the protein kinases activated in the signaling pathways of myocardial adaptation, such as PI3K/Akt pathway, PKA, PKC, ERK1/2, p38 MAPK (Marais et al. 2008). The prosurvival effect of CREB is based upon preventing apoptosis by targeting $\mathrm{Bcl}-2$ protein, DNA damage-inducible protein (GADD34) and gene expression of growth factors such as insulin and fibroblast growth factor 6 (Ichiki 2006). The CREB activation leads also to overexpression of fibronectin, myosin heavy chain coupled with impaired heart function (Ischiki 2006, Pandya and Smithies 2011). However, the overexpression of these structural elements and heart failure was described in longer period of hyperglycemia due to insulin resistance (Qi et al. 2015, Turner et al. 2016). This is consistent with the evidence that resulting effect of several pathological conditions likewise DM to heart resistance against ischemia depends on their duration and falls with their transition to chronicity due to developing of cardiopathies (Ravingerová et al. 2012).

Besides the considered protective effect of acute $\mathrm{HO}$, it seems that HO switches off the beneficial effect of IP on heart resistance against $\mathrm{I} / \mathrm{R}$ injury. IP in $\mathrm{HO}$ conditions enlarged the size of infarction and tended to elevate release of h-FABP from the hearts at the end of reperfusion in comparison with non-preconditioned controls (Figs 1A and 1C). Mild cell swelling induced at the beginning of brief reperfusion periods in IP-episodes supports the release of IP-mediators from the risk myocardium and thereby triggering of cell signaling able to induce an adaptive response. Therefore, the HO conditions may play a pivotal role in a failure of IP to induce cardioprotection. Moreover IP and HO induced in in vitro are acute stress conditions that despite the induction of adaptive mechanisms mediated by Akt, PKCE (Downey et al. 2007, Yeshao et al. 2005, Zhuang et al. 2000) may play role in activation of $\mathrm{PKC} \delta$ (Simkhovich et al. 2013, Shizukuda et al. 2002), involved in apoptotic processes (Zhao et al. 2012). The role of PKC $\delta$ in IP is not clear; the experimental studies demonstrated both activation (Kawamura et al. 1998) or inhibition (Churchill et al. 2010) of $\mathrm{PKC} \delta$ translocation to the membrane structures. Therefore, the combinated administration of both IP and HO should increase the probability of this proapoptotic pathway. The possible potentiated activation of PKC $\delta$ by simultaneously induced IP and $\mathrm{HO}$ often related with hyperglycemic 
conditions could be one of the possible explanations of the negative effect of IP on heart resistance against $\mathrm{I} / \mathrm{R}$ injury. It is tempting to speculate that simultaneous hyperactivation of $\mathrm{PKC} \delta$ by IP and hyperglycemiarelated HO may explain the loss of antinecrotic protection elicited by IP. We acknowledge as limitation of our study the fact that we did not assess PKC $\delta$. Also, we may further speculate that increased osmotic pressure in plasma may explain the negative effect of angina pectoris with respect to prognosis of infarction in patients with comorbidities (diabetes mellitus with angina pectoris).

In conclusion, our results unequivocally confirm that hyperosmolarity is cardioprotective against I/R injury in isolated rat hearts. However, $\mathrm{HO}$ blunted protective effect of IP and increased sensitivity to $I / R$ injury in the preconditioned hearts. The mechanisms underlying the loss of conditioning-related protection in the setting of $\mathrm{HO}$ are currently under investigation. The probable cause of abrogated heart resistance due to combination of more stress stimuli (short-term ischemia and hyperosmosis) and molecular cell death mechanisms are the subjects of further investigation.

\section{Conflict of Interest}

There is no conflict of interest.

\section{Acknowledgements}

The authors express their gratitude to Mrs. Formánková for her excellent technical assistance. This project was supported by grants: VEGA SR 1/0638/12, VEGA SR 2/0201/15, APVV-0102-11, APVV-0241-11, APVV-150607, APVV-15-0119.

\section{References}

ALFIERI RR, PETRONINI PG: Hyperosmotic stress response: comparison with other cellular mechanism. Pflugers Arch 454: 173-185, 2007.

ALHADI HA, FOX KAA: Do we need additional markers of myocyte necrosis: the potential value of heart fatty acid binding protein. Q J Med 97: 187-198, 2004.

BALAKUMAR P: Implicatoon of fundamental signalling alteration in diabetes mellitus-associated cardiovascular disease. Indian Biochem Biophysic 51: 441-448, 2014.

BEHAR S, REICHER-REIS H, ABINADER E, AGMON J, FRIEDMAN Y, BARZILAI J, KAPLINSKY E, KAULI N, KISHON Y, PALANT A: The prognostic significance of angina pectoris preceding the occurrence of a first acute infarction in 4166 consecutive hospitalized patients. Am Heart J 123: 1481-1486, 1992.

CAO Y, WANG L, CHEN H, LV Z: Benefitial effect of hyperosmotic perfusion in the myocardium after ischemia/reperfusion injury in isolated rat hearts. Rev Bras Cir Cardiovasc 28: 54-60, 2013.

CARLSON RE, AISEN AM, BUDA AJ: Effect of reduction in myocardial edema on myocardial blood flow and ventricular function after coronarry reperfusion. Am J Physiol 262: 641-648, 1992.

CHEN H, SHEN WL, WANG XH, CHEN HZ, GU JZ, FU J, NI YF, GAO PJ, ZHU DL, HIGASHINO H: Paradoxically enhanced heart tolerance to ischaemia in type I diabetes and role of increased osmolarity. Clin Exp Pharm Phys 33: 910-916, 2006.

CHIONG M, PARRA V, EISNER V, IBARRA C, MAKDONADO C, CRIOLLO A, BRAVO R, QUIROGA C, CONTRERAS A, VICENCIO JM, CEA P, BUCAREY JL, MOLGÓ J, JAIMOVICH E, HIDALGO C, KROEMER G, LAVANDERO S: Parallel activation of $\mathrm{Ca}(2+)$-induced survival and death pathways in cardiomyocytes by sorbitol-induced hyperosmotic stress. Apoptosis 15: 887-903, 2010.

CHURCHIL EN, FERREIRA JC, BRUM PC, SZWEDA LI, MOCHLY-ROSEN D: Ischemic preconditioning improves proteasomal activity and increases the degradation of $\delta \mathrm{PKC}$ during reperfusion. Cardiovasc Res $\mathbf{8 5}$ : 385-394, 2010.

DOWNEY JM, DAVIS AM, COHEN MV: Signaling pathways in ischemic preconditioning. Heart Fail Rew 12: 181-188, 2007.

FERDINANDY P, SCHULZ R, BAXTER GF: Interaction of cardiovascular risk factors with myocardial ischemia/reperfusion injury, preconditioning, and postconditioning. Pharmacol Rev 59: 418-458, 2007.

GARCIA-DORADO D, THEROUX P, MUNOZ R, ALONZO J, ELIZAGA J, FERNANDEZ-AVILÉS F, BOTAS J, SOLARES J, SORIANO J, DURAN JM: Favorable effect of hyperosmotic reperfusion on myocardial edema and infarct size. Am J Physiol 262: 17-22, 1992. 
ISHIHARA M, INOUNE I, KAWAGOU T, SHIMATI Y, KURISU S, NISHIOKA K, KOUNO Y, UMEMURA T, NAKAMURA S, SATO H: Diabetes mellitus prevents ischemic preconditioning in patients with a first acute anterior wall myocardial infarction. $J$ Am Coll Cardiol 38: 1007-1011, 2001.

ISCHIKI T: Role of cAMP response element binding protein in cardiovascular remodeling: good, bad, or both? Arterioscler Tromb Vasc Biol 26: 449-455, 2006.

JIA YZ, SATO S: Evaluation of coronary collateral circulation in early ischemia in rat hearts. A morphological study. Nihon Ika Daikagu Zasshi 64: 329-336, 1997.

KAWAMURA S, YOSHIDA K, MIURA T, MUZIKAMI Y, MATSUZAKI: Ischemic preconditioning translocates PKC- $\delta$ and $\varepsilon$, which mediate functional protection in isolated rat heart. Am J Physiol 275: 2266-2271, 1998.

KERSTEN JR, SCHMELLING TJ, ORTH KG, PAGEL PS, WARLTIER DC: Acute hyperglycemia abolishes ischemic preconditioning in vivo. Am J Med Heart 275: 721-725, 1998.

KLEIN HH, NEBENDAHL K, SCHUBOTHE M, KREUZER H: Intracoronary hyperosmotic mannitol during reperfusion does not affect infarct site in ischemic, reperfused porcine hearts. Basic Res Cardiol 80: 251-251, 1985.

LI YL, HE RR: Protective effect of preconditioning on ischemic heart and characterization of adenozine receptors in ischemic rabbit hearts. Acta Pharm Sin 16: 505-508, 1995.

MARAIS E, GENADE S, LOCHNER A: CREB activation and ischaemic preconditioning. Cardiovasc Drug Ther 22: 3-17, 2008.

NECKÁŘ J, PAPOUŠEK F, NOVÁKOVÁ O, OŠŤÁDAL B, KOLÁŘ F: Cardioprotective effect of chronic hypoxia and ischemic preconditioning are not aditive. Basic Res Cardiol 97: 161-167, 2007.

PANDYA K, SMITIES O: $\beta-$ MyHC and cardiac hypertrophy: size does matter. Circ Res 109: 609-610, 2011.

PHILLIS JW, O'REGAN MH: Evidence for cell swelling-induced adenosine and adenine nucleotide release in rat cerebral cortex exposed to monocarboxylate-containing or hypotonic artificial cerebrospinal fluids. Neurochem Int 40: 629-635, 2002.

QI U, ZHU Q, ZHANG K, THOMAS C, WU Y, KUMAR R, BAKER KM, XU Z, CHEN S, GUO S: Activation of Foxo1 by insulin resistance promotes cardiac dysfunction and $\beta$-myosin heavy chain gene expression. Circ Heart Fail 8: 198-208, 2015.

RAVINGEROVÁ T, ŠTETKA R, VOLKOVOVÁ K, DŽURBA A, ZIEGELHÖFFER A, STYK J: Acute diabetes modulates response to ischemia in isolated rat hearts. Mol Cell Biochem 210: 143-151, 2000.

RAVINGEROVÁ T, BARANČÍK M, STRNISKOVÁ M: Mitogen-activated protein kinases-mediated signaling in cardiac pathology. In: Cardiac Drug Development Guide. PUGSLEY MK (ed.), Human press Inc, 2003a, pp 67-86.

RAVINGEROVÁ T, NECKÁŘ J, KOLÁŘ F: Ischemic tolerance of rat hearts in acute and chronic phases of experimental diabetes. Mol Cell Biochem 249: 167-174, 2003 b.

RAVINGEROVÁ T, ADAMEOVÁ A, MATEJÍKOVÁ J, KELLY T, NEMČEKOVÁ M, KUCHARSKÁ J, PECHÁŇOVÁ O, LAZOU A: Subcellular mechanism of adaptation in the diabetic myocardium: revelance to ischemic preconditioning in the nondiseased heart. Exp Clin Cardiol 15: 68-76, 2010.

RAVINGEROVÁ T, ČARNICKÁ S, NEMČEKOVÁ M, LEDVÉNYIOVÁ V, ADAMEOVÁ A, KHANDELWAL VKM, ZÁLEŠÁK M, KOLÁŘ F: The impact of lifestyle-related risk factors on cardiac response to ischemia and possibilities to restore impaired ischemic tolerance. Physiol Res 61 (Suppl 2): S1-S10, 2012.

TOSAKI A, ENGELMANN DT, ENGELMANN RM, DAS DK: The evolution in diabetic response to ischemia/reperfusion and preconditioning in isolated working rat hearts. Cardiovasc Res 31: 526-536, 1996.

TURNER KD, ZOU K, HINKLEY M, PARK S, ZHENG D, HOUMARD J: Higher cell growth/viability accompained by reduced myosin heavy chain expression in sceletal muscle cell derived from severely obese type 2 diabetic humans. FASEB J 30 (Suppl 1): 770.5, 2016.

SHIZUKUDA Y, REYLAND ME, BUTTRICK PM: Protein kinase C-delta modulates apoptosis induced by hyperglycemia in adult ventricular myocytes. Am J Physiol 282: 1625-1634, 2002.

SIMKHOVICH BZ, PRZYKLENK K, KLONER RA: Role of protein kinase C in ischemic „,conditioning“: from first evidence to current perspectives. J Cardiovasc Pharmacol Ther 18: 525-532, 2013.

ŠTRBÁK V: Cell swelling-induced peptide hormone secretion. Cell Physiol Biochem 28: 1155-1168, 2011. 
VLADIC N, GE ZG, LEUCKER T, BRZEZINSKA AK, DU JH, SHI Y, WARLTIER DC, PRATT PF, KERSTEN JR: Decreased tetrahydrobiopterin and disrupted association of Hps90 with eNOS by hyperglycemia impair myocardial ischemic preconditioning. Am J Physiol 301: 2130-2139, 2011.

YESHAO W, GU J, PENG X, NAIRN AC, NADLER JI: Elevated glucose activates protein synthesis in cultured myocytes. Metabolism 54: 1453-1460, 2005.

ZÁLEŠÁK M, BLAŽÍČEK P, PANCZA D, LEDVÉNYIOVÁ V, BARTEKOVÁ M, NEMČEKOVÁ M, ČARNICKÁ S, ZIEGELHÖFFER A, RAVINGEROVÁ T: Severity of lethal ischemia/reperfusion injury in rat hearts subjected to ischemic preconditioning is increased under conditions of simulated hyperglycemia. Physiol Res 63: 577-585, 2014.

ZHAO M, XIA L, CHEN GQ: Protein kinase C $\delta$ in apoptosis: a brief overview. Arch Immunol Ther Exp (Warsz) 60: 361-372, 2012.

ZHUANG S, HIRAI SI, OHNO S: Hyperosmolarity induces activation of cPKC and nPKC, a requirement for ERK1/2 activation in NIH/3T3 cells. Am J Physiol Cell Physiol 278: 102-109, 2000. 